\title{
Is Galea tixiensis Quintana, 2001 a synonym of G. leucoblephara Burmeister, 1861?
}

\author{
Pablo Teta ${ }^{1,2 *}$ and Denise Heliana Campo ${ }^{1}$ \\ 'División Mastozoología, Museo Argentino de Ciencias Naturales “Bernardino Rivadavia”. Avenida Ángel Gallardo 470, C1405DJR, \\ Buenos Aires, Argentina. E-mail antheca@yahoo.com.ar (PT), deniseheliana@gmail.com (DHC). \\ ${ }^{2}$ Consejo Nacional de Investigaciones Científicas y Técnicas (CONICET). \\ *Correspondencia: antheca@yahoo.com.ar
}

The genus Galea (Rodentia, Caviidae) includes five living and two extinct species of terrestrial and herbivorous cavies that inhabit grasslands and rocky scrub areas at both high and low elevations in South America. Fossil samples from the late Pleistocene-Holocene from central-eastern Argentina have been referred to as Galea sp., $G$ musteloides or G. cf. musteloides and finally described as a new species under the name of G. tixiensis. However, recent studies based on large series of individuals fail to find qualitative morphological differences between $G$. leucoblephara and $G$. tixiensis. Based on these findings, in this contribution we reviewed the taxonomic status of the fossil species G. tixiensis. A total of 110 individuals of the three currently recognized subspecies of G. leucoblephara (i. e., G. I. demissa, G. I. leucoblephara and G. I. littoralis) from Argentina Bolivia and Paraguay were examined. Nine craniodental measurements were recorded. Quantitative data were subjected to a principal component analysis (PCA) in order to identify the contribution of each measurement to the total variance. Qualitative characters were evaluated through the comparisons of the diagnostic traits of $G$. tixiensis with the variability derived from the recent samples. PCA showed a high overlap of the multivariate spaces of the three subspecies studied, suggesting that they do not differ significantly in terms of cranial shape. The holotype of $G$. tixiensis was allocated within the morphospace of the recent $G$. I. littoralis samples. Qualitative traits diagnostic of $G$. tixiensis were also recorded in recent samples of $G$. leucoblephara, in particular of $G$. I. littoralis. Based on both qualitative and quantitative cranial traits, we suggest that $G$. tixiensis is a synonym of $G$. leucoblephara. The morphological traits supposedly unique to $G$. tixiensis were also recorded in specimens of living populations of G. I. littoralis. The large values of some quantitative cranial traits in fossil samples -- compared to living ones -- are reinterpreted here as an ecophenotypical response to the more severe climatic conditions of the Holocene.

El género Galea (Rodentia, Caviidae) incluye cinco especies vivientes y dos extintas de cávidos terrestres y herbívoros, que ocupan pastizales y matorrales rocosos, tanto en áreas altas como bajas de América del Sur. Algunas muestras fósiles del Pleistoceno-Holoceno del centro-este de Argentina han sido referidas como Galea sp., G. musteloides o G. cf. musteloides y finalmente se describieron como una nueva especie bajo el nombre de G. tixiensis. Sin embargo, estudios recientes basados en series grandes de individuos fallaron en encontrar diferencias morfológicas cualitativas entre G. lecucoblephara y G. tixiensis. Sobre la base de estos hallazgos, en esta contribución revisamos el estatus taxonómico de la especie extinta G. tixiensis. Se examinaron 110 individuos de las tres subespecies actualmente reconocidas de G. leucoblephara (i.e., G. I. demissa, G. I. leucoblephara y G. I. littoralis) de Argentina, Bolivia y Paraguay. Se registraron nueve medidas cráneo-dentarias. Los datos cuantitativos se sometieron a un análisis de componentes principales (PCA) con el fin de identificar la contribución de cada medida a la varianza total. Los caracteres cualitativos se evaluaron a través de las comparaciones de los rasgos supuestamente diagnósticos de G. tixiensis con la variabilidad representada por las muestras recientes. Los espacios multivariados de las tres subespecies estudiadas se superpusieron ampliamente en el PCA, lo que sugiere que estos taxones no difieren significativamente en la figura del cráneo. El holotipo de G. tixiensis se ubicó dentro del morfoespacio correspondiente a muestras recientes de G. I. littoralis. Los caracteres cualitativos supuestamente diagnósticos de $G$. tixiensis también se verificaron en muestras recientes de G. leucoblephara, en particular de G. I. littoralis. Sobre la base de sus rasgos craneanos cualitativos y cuantitativos se sugiere que $G$. tixiensis es un sinónimo de G. leucoblephara. Los mayores valores para algunos rasgos craneanos cuantitativos en las muestras fósiles -comparadas con las actuales- son reinterpretados en este trabajo como una respuesta ecofenotipica a las condiciones climáticas más severas durante el Holoceno.

Key words: Caviidae; Cavioidea; Caviomorpha; Galea leucoblephara littoralis; Hystricognathi.

C 2017 Asociación Mexicana de Mastozoología, www.mastozoologiamexicana.org

\section{Introduction}

The genus Galea Meyen 1833, with five living and two extinct species, is one of the most diverse genera within the Family Caviidae (Ubilla and Rinderknecht 2014; Dunnun 2015). Its fossil record dates back at least to the Ensenadense (Vucetich et al. 2015) and is composed mainly of fragmentary cranio-mandibular remains (Ubilla and Rinderknecht 2014). The only two known extinct species (i. e., G. orthodonta Ubilla and Rinderknecht 2001 and G. tixiensis Quintana 2001) are based on well preserved craniodental and postcranial remains. The former of these species,
G. orthodonta, has been found in Pleistocene sediments of Uruguay and southern Bolivia (Ubilla and Rinderknecht 2001; Ubilla and Rinderknecht 2014). The second extinct species, Galea tixiensis, was established from remains accumulated throughout the Holocene in rocky outcrops in the southeast of Province of Buenos Aires, in east-central Argentina (Quintana 2001). The materials that led to the description of G. tixiensis were instead referred to as either Galea sp., G musteloides or G. cf. musteloides (e. g., Tonni et al. 1988; Quintana and Mazzanti, 1998; Quintana 2001), highlighting its morphological similarity with individuals of the recent 
populations inhabiting this same region, firstly referred to G. musteloides and now allocated within G. leucoblephara (Dunnun 2015). Quintana (2001) indicated several diagnostic traits for Galea tixiensis (see below), in addition to larger size relative to other species in the same genus. Unfortunately, Quintana (2001) did not document what living specimens were compared against the fossil samples, nor some other relevant aspects that are key for the description of a new species, such as holotype measurements (which were not illustrated either). More recently, a species related to $G$. tixiensis, referred to as $G$. aff. tixiensis, was mentioned for the Pleistocene of Province of Corrientes, in northeast Argentina (Francia et al. 2012).

The examination of a vast number of specimens as part of a qualitative and quantitative morphologic review of the genus Galea allows us to assume that many of the diagnostic traits of $G$. tixiensis are not unique to this species, and neither is the combination of these traits (see also Ubilla and Rinderknecht 2014). The taxonomic status of G. tixiensis is relevant for several reasons (e. g., biogeographic, evolutionary), but mainly because, should this be a distinct species, it would be one of the eight species of mammals that became extinct over the past 500 years in mainland South America (cf. Teta et al. 2014; Prevosti et al. 2015).

The aim of this work is to review the taxonomic status of Galea tixiensis. Based on qualitative and quantitative morphological evidence, it is hypothesized that G. tixiensis is synonym for Galea leucoblephara Burmeister 1861.

\section{Materials and Methods}

We studied 110 specimens of Galea leucoblephara, including skulls and mandibles, from Argentina, Bolivia and Paraguay. These are deposited in the following collections (for details, see Appendix 1): CFA, Collection of Mammals of Fundación de Historia Natural Félix de Azara (Buenos Aires, Argentina); $\mathrm{CMI}$, Collection of Mammals of Instituto Argentino de Investigación de Zonas Áridas (Instituto Argentino de Investigaciones de Zonas Áridas, Mendoza, Argentina); CML, Collection of Mammals of Facultad de Ciencias Naturales e Instituto Miguel Lillo (Facultad de Ciencias Naturales e Instituto Miguel Lillo, San Miguel de Tucumán, Argentina); CNP, Collection of Mammals of Centro Nacional Patagónico (Centro Nacional Patagónico, Puerto Madryn, Argentina) MACN-Ma, Museo Argentino de Ciencias Naturales "Bernardino Rivadavia" (Buenos Aires, Argentina) MNHNP, Collection of Mammals of Museo Nacional de Historia Natural de Paraguay (Asución, Paraguay); UACh, Collection of Mammals of Universidad Austral de Chile (Valdivia, Chile). Samples were grouped into 3 major geographical groups, allocated to subspecies G. leucoblephara demissa, G. I. leucoblephara and G. I. littoralis, following the taxonomic scheme proposed by Bezerra (2008) and Dunnun (2015). The first of these taxa is distributed across the lowlands of southeastern Bolivia and western Paraguay to the Provinces of Santiago del Estero and Catamarca in Argentina; the second, from southern Catamarca to Córdoba and northern Mendoza and San Luis, in
Argentina; and the third, from southern Mendoza, La Pampa and southeastern Buenos Aires to northeastern Santa Cruz, in Argentina.

The following cranial measurements were recorded for each adult specimen (classes 3-5; cf. (sensu Bezerra 2008) (using a digital caliper accurate to $0.01 \mathrm{~mm}$ ): $\mathrm{AN}=$ nasal width; $\mathrm{CIO}=$ interorbital constriction; $\mathrm{FL}=$ frontal length; $\mathrm{LD}=$ diastema length; $\mathrm{AFI}=$ incisive foramen width; $\mathrm{LFI}=$ incisive foramen length; $L P=$ palatilar length; $S M S=$ length of the upper toothrow length (alveolar); APM3 = palate width at the third upper molar. The measurements of the holotype of $G$. tixiensis were estimated using the software tpsdig2 from photographs in Bezerra (2008) and Francia et al. (2012), using as reference the scale in the latter.

To summarize the causes of morphometric variation and rank them according to importance, a principal components analysis (PCA) was performed from a variancecovariance matrix of the log-transformed measures. Previously, each individual measurement was corrected by the geometric mean of each individual to avoid the distortion derived from the effect of size (for this methodology, see Meachen-Samuels and Van Valkenburgh 2009). For the purposes of this work, form is defined as the appearance, configuration or composition of the traits, including size, whereas figure refers to the form excluding size (Vizcaíno et al. 2016). This is consistent with the approach of Richtsmeier et al. (2002), in his attempt to circumvent the use of these terms in the colloquial sense.

The anatomical terminology corresponds to the one used by Cherem and Ferrigolo (2012). The qualitative and quantitative morphological traits of Galea tixiensis were taken from the literature (i. e., Quintana 2001) and discussed from the comparison with recent specimens.

\section{Results}

The first two PCA axes accounted for $63.1 \%$ of the variation in craniodental measurements (Figure 2; Table 2). The overlap of the polygons corresponding to the three subspecies currently recognized was moderate to high, suggesting that there are no major differences in figure. In this context, the holotype of G. tixiensis was allocated with G. I. littoralis specimens (Figure 2), toward positive values in PC 1 . All the variables were negatively correlated with PC 1, except AFI, which was positively correlated.

The states for morphological traits originally referred to as diagnostic for $G$. tixiensis were also observed in living specimens of $G$. leucoblephara. The morphological variability recorded in different qualitative features of the fossil taxon is well within the variability documented for the living populations of G. leucoblephara, but especially of $G$. I. littoralis (for a summary see Table 3 ).

\section{Discussion}

The most striking feature of $G$. tixiensis relative to other species in the same genus is its larger overall size (Quintana 

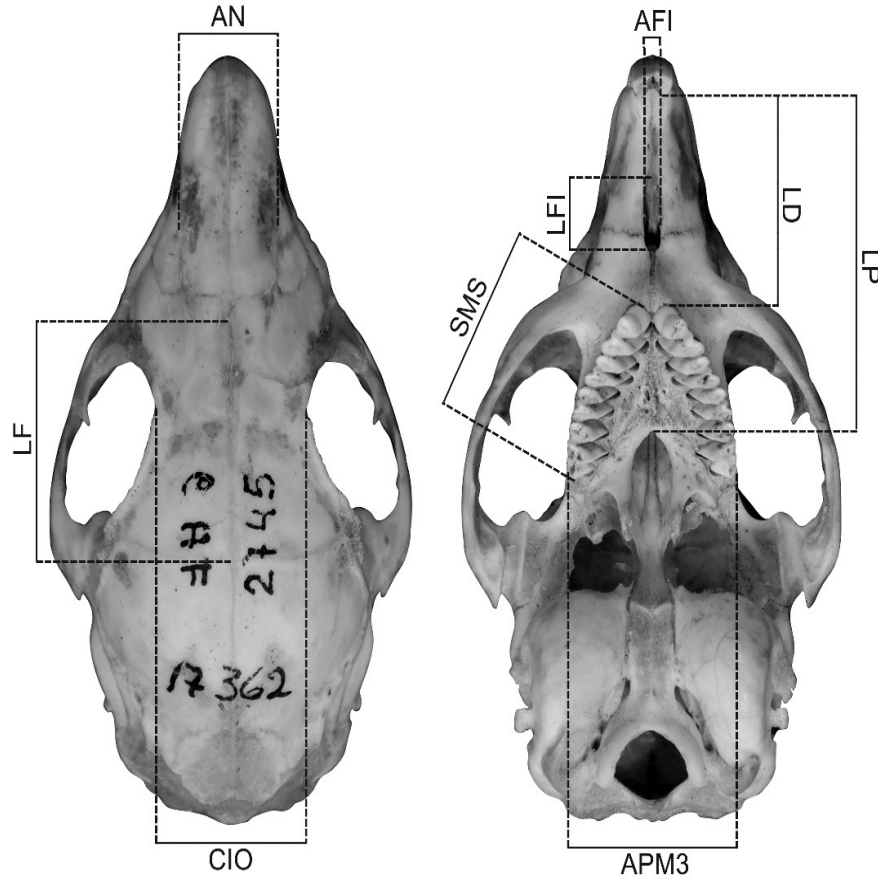

Figure 1. Cranial measurements used in this study, shown on a skull of Galea leucoblephara (MACN 17362). For a reference of the abbreviations, see Materials and Methods.

2001:404). However, a size-adjusted PCA indicates that, in terms of figure, the $G$. tixiensis holotype does not differ from other individuals referred to as G. leucoblephara. This is not a minor issue, as certain quantitative traits are among the phenotypic variables most frequently associated with physiological or environmental changes (e. g., Maestri et al. 2016). Also, some differences might be magnified by the different sample sizes considered by previous authors. For example, for a set of 35 individuals of G. leucoblephara, Quintana (2001) reported a higher mean upper alveolar toothrow length of $11.77 \mathrm{~mm}$, with a range between 10.4 to11.7 $\mathrm{mm}$ ( $n=35$; note the contradiction between the mean and maximum values recorded), while for the same species, with a sample three times larger $(n=110)$, we recorded an average of $11.82 \mathrm{~mm}$ and a range of 10.1 to $15.54 \mathrm{~mm}(n=110)$. This evidences that although the mean value remains clearly lower for $G$. leucoblephara, the range of measurements for this species covers completely the range reported for $G$. tixiensis (mean $=13.18 \mathrm{~mm} ; 12.2-15.1$ $\mathrm{mm}$ range; $\mathrm{n}=107$ ).

Our review of extensive series of specimens indicates that none of the qualitative traits supposedly diagnostics of G. tixiensis, nor the combination of them, is unique to this taxon. For example, the morphology of the zygomatic arch and the diastema and its associated foramina does not differ significantly from the one observed in living specimens of G. I. littoralis (cf. Figures 3 and 4; Table 3). In this subspecies, the shape of the incisive foramen varies between tapered and diamond-shaped, together with the presence of a conspicuous interpremaxillar foramen, accompanied by accessory foramina with a lateral and posterior arrangement, in a disposition similar to that reported for G. tixiensis (Figure 3). This contradicts what has been pointed out by Quintana

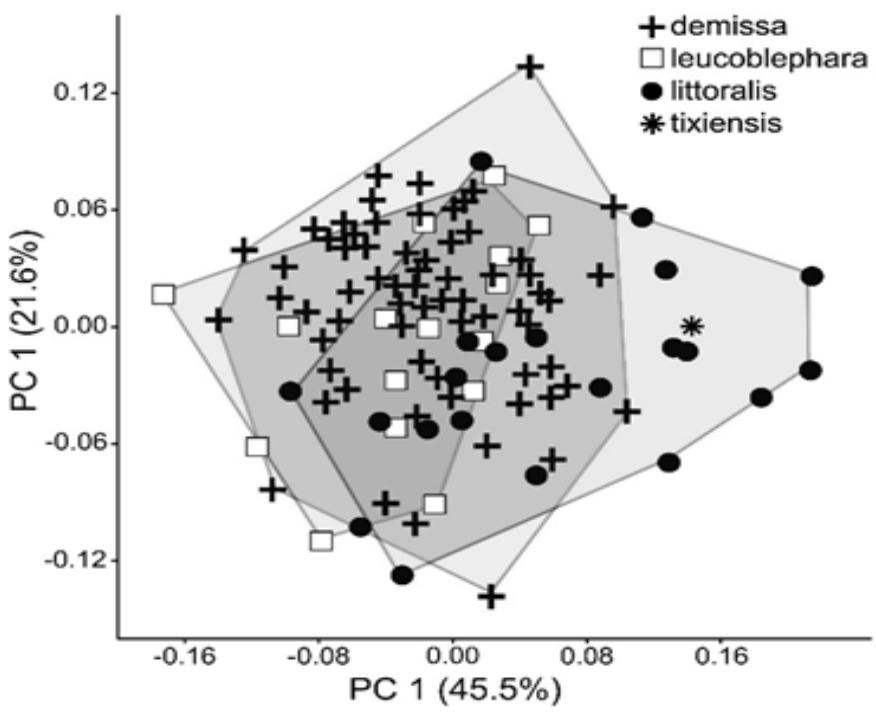

Figure 2. Polygons and individual scores for adult specimens $(n=111)$ in three subspecies of Galea leucoblephara and the holotype of G. tixiensis for principal components 1 and 2 (obtained from a variance-covariance matrix on nine craniodental measurements corrected by the geometric mean).

(2001:402 to 404), who indicated that the diamond shape of the incisive foramen was exclusive to the fossil species and that the accessory foramina were not present in other species, nor did this displayed the overall disposition as $G$. tixiensis. Also, the robustness of the zygomatic arch, as well as the development of the paraorbital apophysis on the ascending branch of the zygomatic portion of the maxilla and the size of the jugal were relatively variable in samples of the living specimens, with some individuals (e. g., MACNMa 13335; cf. Figure 4B) displaying a disposition similar to the one observed in G. tixiensis (cf. Quintana 2001; Fig. 3A). Other traits (e. g., shape of the mesopterygoid fossa, shape of the nasolacrimal foramen, appearance of the tympanic bulla, morphology of the mandibular ramus and molars) did not show major differences between $G$. tixiensis and G. leucoblephara (cf. Quintana 2001; this work). For all the above mentioned, we consider that there is no qualitative morphological evidence to suggest that $\mathrm{G}$. tixiensis is a different species from $G$. leucoblephara.

For Quintana (2001), G. tixiensis became extinct toward
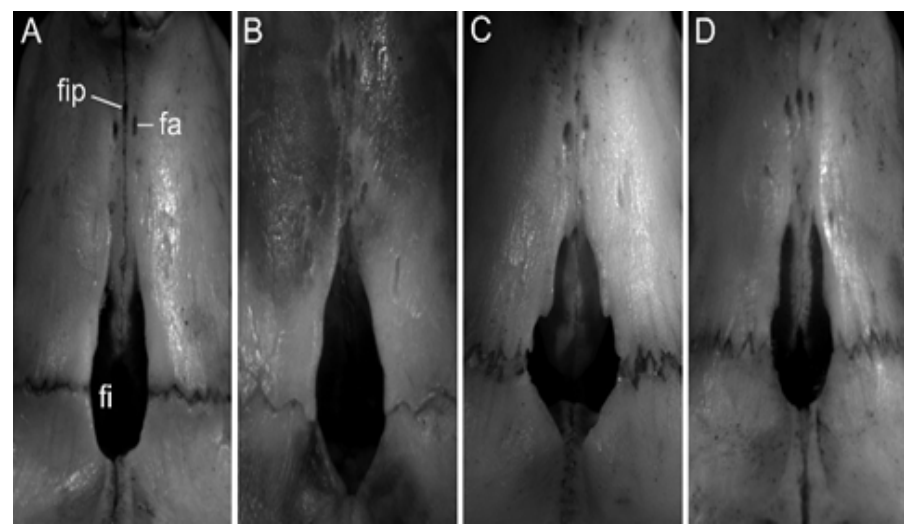

Figure 3. Individual variation in the morphology of incisive foramina and associated structures in specimens of Galea leucoblephara littoralis (from left to right: MACNMa 13226, 22607, 16405, 13664). Abbreviations: fa = lateral accessory foramina; fip = interpremaxillar foramen. 


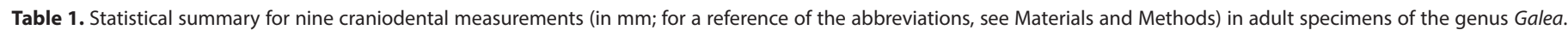
Other abbreviations: $\mathrm{N}=$ number of specimens measured; $\mathrm{SD}=$ standard deviation; $\mathrm{Min}=$ minimum recorded value; Max. = maximum recorded value.

\begin{tabular}{|c|c|c|c|c|c|c|c|c|c|c|c|c|c|c|c|c|}
\hline & \multicolumn{5}{|c|}{ G. leucoblephara demissa } & \multicolumn{5}{|c|}{ G. leucoblephara leucoblephara } & \multicolumn{5}{|c|}{ G. leucoblephara littoralis } & \multirow[t]{2}{*}{ G. tixiensis } \\
\hline & $\mathrm{N}$ & Mean & SD & Min. & Max. & $\mathrm{N}$ & Mean & SD & Min. & Max. & $\mathrm{N}$ & Mean & SD & Min. & Max. & \\
\hline AN & 71 & 7.39 & 0.56 & 6.27 & 8.91 & 18 & 7.18 & 0.42 & 6.52 & 8.08 & 21 & 6.98 & 0.44 & 6.42 & 8.20 & 7.83 \\
\hline $\mathrm{ClO}$ & 71 & 10.89 & 0.79 & 8.89 & 13.06 & 18 & 10.32 & 0.87 & 8.55 & 12.36 & 21 & 10.64 & 0.50 & 9.47 & 11.49 & 11.74 \\
\hline LF & 71 & 16.34 & 0.90 & 13.58 & 18.36 & 18 & 16.36 & 2.13 & 10.03 & 19.91 & 21 & 17.08 & 0.90 & 15.69 & 19.23 & 16.86 \\
\hline LD & 71 & 12.93 & 1.11 & 10.84 & 15.25 & 18 & 13.55 & 1.05 & 11.81 & 15.25 & 21 & 13.27 & 0.89 & 11.35 & 15.13 & 15.85 \\
\hline AFI & 71 & 1.44 & 0.22 & 1.02 & 2.04 & 18 & 1.40 & 0.21 & 1.00 & 1.75 & 21 & 1.72 & 0.38 & 1.16 & 2.51 & 2.39 \\
\hline LFI & 71 & 4.50 & 0.56 & 3.14 & 6.19 & 18 & 4.38 & 0.58 & 3.02 & 5.43 & 21 & 4.15 & 0.48 & 3.16 & 5.20 & 5.05 \\
\hline LP & 71 & 11.79 & 0.92 & 10.10 & 15.52 & 18 & 11.95 & 1.22 & 10.41 & 15.54 & 21 & 11.81 & 0.72 & 10.70 & 13.52 & 13.96 \\
\hline SMS & 71 & 20.92 & 1.58 & 17.72 & 24.48 & 18 & 20.79 & 2.57 & 12.20 & 23.83 & 21 & 21.29 & 1.19 & 17.83 & 23.45 & 15.00 \\
\hline APM3 & 71 & 12.60 & 0.75 & 10.97 & 14.22 & 18 & 12.77 & 0.69 & 11.48 & 13.88 & 21 & 12.90 & 0.70 & 11.88 & 14.56 & 25.58 \\
\hline
\end{tabular}

the 18th century, in accordance with the earliest records of exotic wildlife in the southeast of the Province of Buenos Aires, during a period of cold and dry climate referred to as the Little Ice Age. If his hypothesis is correct, G. tixiensis would have been replaced in those same ecosystems by G. I. littoralis, the species currently recorded in the south of the pampas region (Galliari et al. 1991). In other words, the colonization of G. I. littoralis would have occurred in the last 200 years after the extinction of $G$. tixiensis, since there are no references of both species coexisting in sympatry in any of the sites studied by Quintana (2001; see also Quintana, 2016a, 2016b). This hypothesis is hardly parsimonious, especially in view of the morphological results discussed above. It is more likely that G. leucoblephara had experienced changes in size throughout the Holocene, a phenomenon that is well documented for mammals of the Northern Hemisphere (Martin and Barnosky 1993). In fact, the record of Holocene mammals of larger sizes than their living counterparts has already been mentioned for hilly and interhilly

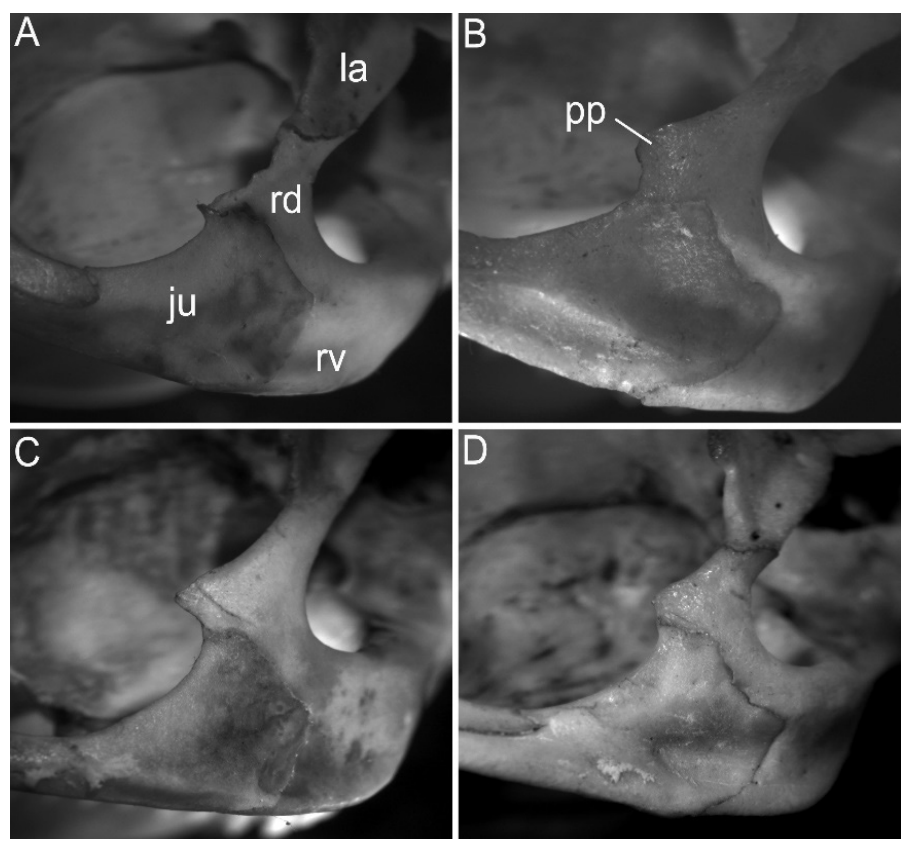

Figure 4. Individual variation in the morphology of the orbit in specimens of Galea leucoblephara littoralis: A) MACN-Ma 16405; B) MACN-Ma 13335; C) MACN-Ma 22607; D) MACN-Ma 13226. Abbreviations: ju = jugal; = lacrimal; $\mathrm{pp}=$ paraorbital apophyses; rd/rv $=$ dorsal/ventral root of the zygomatic portion of the maxilla. areas of Buenos Aires. A number of authors have highlighted the findings in various archaeological and fossils sites, of specimens of the rodent Dolichotis patagonum ( $e$. g., Lobería; Tonni 1985) and the xenarthran Zaedyus pichiy (e. g., La Toma, Fortín Necochea, Laguna del Trompa, San Martín; see Vizcaíno et al. 1993) based on skeletal remains of larger size vs living specimens. A similar finding has been described for the cervid Ozotocerus bezoarticus and the sigmodontine rodent Holochilus vulpinus in several sites in the hilly area of Cordoba, central Argentina, for the same period of time (Teta et al. 2005; Medina and Merino 2012).

The climatic conditions for the largest part of the Holocene in the Pampean region were colder and drier than the current climate (cf. Tonni et al. 1999). In this context, it would not be unlikely that some mammal lineages likely developed phenotypic and physiological responses consistent with this scenario, including the variation in size, but not necessarily implying speciation events.

\section{Acknowledgments}

S. Lucero collaborated in the measurement of specimens and facilitated our work in the Museo Argentino de Cien-

Table 2. Results of the principal component analysis performed on adult individuals ( $n=111$ ) of three subspecies of Galea leucoblephara and the holotype of G. tixiensis. For a reference of the abbreviations, see Materials and Methods.

\begin{tabular}{llll}
\hline & PC 1 & PC 2 & PC 3 \\
\hline AN & -0.14 & 0.01 & 0.43 \\
CIO & -0.06 & -0.06 & 0.71 \\
LF & -0.11 & -0.13 & -0.41 \\
LD & -0.14 & -0.26 & -0.31 \\
AFI & 0.94 & 0.05 & -0.04 \\
LFI & -0.17 & 0.90 & -0.15 \\
LP & -0.12 & -0.24 & -0.11 \\
SMS & -0.09 & -0.13 & -0.08 \\
APM3 & -0.10 & -0.14 & -0.05 \\
Autovalues & 0.01 & 0.00 & 0.00 \\
\% Variance & 45.14 & 21.60 & 10.59 \\
\hline
\end{tabular}




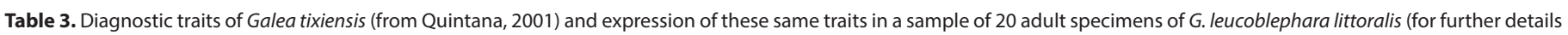
see Appendix 1).

\begin{tabular}{|c|c|c|}
\hline & G. tixiensis & G. I. littoralis \\
\hline Size & Larger than in living populations of G. I. littoralis & Smaller than in G. tixiensis \\
\hline Zygomatic arches & Robust & Robust to moderately robust \\
\hline Jugal & Proportionately short and wide & Proportionately short and wide to short and thinner \\
\hline $\begin{array}{l}\text { Ascending branch of the zygomatic } \\
\text { portion of the maxilla }\end{array}$ & $\begin{array}{l}\text { Proportionately short, with a well-defined paraorbital } \\
\text { apophysis }\end{array}$ & $\begin{array}{l}\text { Proportionately short, with a moderately to well-defined } \\
\text { paraorbital apophysis }\end{array}$ \\
\hline Ventral surface of the diastema & Flat in front of the incisive foramina & Flat in front of the incisive foramina \\
\hline Incisive foramen & Large and diamond-shaped & Large, tapered to diamond-shaped \\
\hline Interpremaxillar foramen & $\begin{array}{l}\text { Large with two accessory foramina located with a lateral and } \\
\text { posterior disposition, forming a structure that is connected } \\
\text { to the incisive foramen through two open channels that } \\
\text { cover the premaxilla on the lower side of the diastema }\end{array}$ & $\begin{array}{l}\text { Large to medium in size, with two accessory foramina located to } \\
\text { the sides and back, with the same disposition and connection } \\
\text { with the incisive foramen as in } G \text { tixiensis. }\end{array}$ \\
\hline
\end{tabular}

cias Naturales "Bernardino Rivadavia". We thank the curators of the collections visited, for allowing us access to the materials studied: S. Bogan (CFA), R. Barquez and M. M. Diaz (CML), I. Gamarra (MNHNP), R. Ojeda and B. Bender (CMI) and U. F. J. Pardiñas (CNP), G. D'Elía (UACh). Two anonymous reviewers and G. D'Elia as associate editor contributed their suggestions to improve the clarity of the manuscript. Some of the ideas expressed in this manuscript were discussed with U. F. J. Pardiñas and F. Fernandez. The holotype and other materials referred to Galea tixiensis were requested on several occasions to the Archeology Laboratory of the Faculty of Humanities (National University of Mar del Plata, Argentina), which is where they are deposited, but by being assigned to other research projects (C. Quintana, com. epist.) could not be reviewed; nor was a likely date indicated for doing so. María Elena Sánchez-Salazar translated the manuscript into English.

\section{Literature cited}

BezerRA, A. 2008. Revisão taxonômica do gênero Galea Meyen, 1832 (Rodentia,Caviidae, Caviinae) Dissertation, Universidad de Brasilia, Brasília, Brazil.

Cherem, J. J., AND F. Ferigolo. 2012. Descricão do sincrânio de Cavia aperea (Rodentia,Caviidae) e comparacão com as demais espécies do gênero no Brasil. Papeis Avulsos de Zoología 52:21-50.

Dunnum, J. L. 2015. Family Caviidae G. Fischer, 1817. Pp. 690-726 in Mammals of South America, Volume 2 - Rodents (Patton, J.L., U.F.J. Pardiñas y G. D'Elía, eds.). The University of Chicago Press, Chicago, Illinois.

Francia, A., A. A. Carlini, A. E. Zurita, and D. H. Verzi. 2012. Galea (Rodentia, Caviidae) in the late Pleistocene of Corrientes Province (Argentina): taxonomic and paleobiogeographic implications. Neues Jahrbuch für Geologie und Paläontologie 266/2:173-184.

Galliarl, C. A., W. D. Berman, and F. J. Goln. 1991. Situación ambiental de la provincia de Buenos Aires. A. Recursos y rasgos naturales en la evaluación ambiental. Mamíferos. Comisión de Investigaciones Científicas de la provincia de Buenos Aires, año I, 5:1-35.

Maestri, R., R. Fornel, G. L. Gonçalves, L. Geise, T. R. O. de Freitas, and
A. C. Carnaval. 2016. Predictors of intraspecific morphological variability in a tropical hotspot: comparing the influence of random and non-random factors. Journal of Biogeography 43:2160-2172.

Martin, R. A., AND A. D. BARnosky. 1993. Morphological Change in Quaternary Mammals of North America. Cambridge, UK: Cambridge University Press.

Meachen-Samuels, J., and B. Van Valkenburgh. 2009. Craniodental indicators of prey size preference in the Felidae. Biological Journal of the Linnean Society 96:784-799.

Medina, M. E., AND M. L. Merino. 2012. Zooarqueología de Puesto La Esquina 1 (ca. 360 AP, Pampa de Olaen, Córdoba). Su importancia biogeográfica y paleoecológica. Intersecciones en Antropología 13:473-484.

Prevosti, F. J., M. A. Ramírez, M. Schiaffini, F. Martin, D. E. Udrizar Sauthier, M. Carrera, C. Sillero-Zubiri, and U. F. J. Pardinas. 2015. Extinctions in near time: new radiocarbon dates point to a very recent disappearance of the South American fox Dusicyon avus (Carnivora: Canidae). Biological Journal of the Linnean Society 116:704-720

Quintana, C. 2001. Galea (Rodentia, Caviidae) del Pleistoceno Superiory Holoceno de las sierras de Tandilia oriental, provincia de Buenos Aires, Argentina. Ameghiniana 38:399-407

QuintanA, C. 2016a. Tafonomía de los microvertebrados del sitio arqueológico, Cueva Tixi (Pleistoceno tardíoHoloceno tardío), Tandilia Oriental (provincia de Buenos Aires, Argentina). Publicación Electrónica de la Asociación Paleontológica Argentina 16:14-51.

QuintanA, C. 2016b. Microvertebrados del sitio arqueológico Cueva El Abra, Tandilia oriental: tafonomía y paleoambiente. Comechingonia, Revista de Arqueología 20:203-229.

Quintana, C., And D. L. Mazzanti. 1998. Roedores Caviidae del Pleistoceno Superior y Holoceno de sitios arqueológicos de Tandilia oriental, provincia de Buenos Aires. V Jornadas Geológicas y Geofísicas Bonaerensas 259-263.

Richtsmeier, J.T., V.B. DeLeon, and S.R. Lele. 2002 The promise of geometric morphometrics. Yearbook of Physical Anthropology 45:63-91.

Teta, P., M. Medina, S. Pastor, D. Rivero, and H. Paradela. 2005. Holochilus brasiliensis (Rodentia, Cricetidae) en conjuntos arqueofaunísticos del Holoceno tardío de la provincia de Córdoba (Argentina). Mastozoología Neotropical 12:271-275. 
Teta, P., A. Formoso, M. Tammone, D. C. de Tommaso, F. J. Fernández, J. Torres, AND U. F. J. PARdiñAS. 2014. Micromamíferos, cambio climático e impacto antrópico: ¿Cuánto han cambiado las comunidades del sur de América del Sur en los últimos 500 años? Therya 5:7-38.

TonnI, E.P. 1985. Mamíferos del Holoceno del Partido de Lobería, provincia de Buenos Aires. Aspectos paleoambientales y bioestratigráfico del Holoceno del sector oriental de Tandilia y área Interserrana. Ameghiniana 22:284-288.

Tonnl, E. P., M. BARgo, ANd J. Prado. 1988. Los cambios ambientales en el Pleistoceno tardío y Holoceno del S.E. de la Prov. de Buenos Aires a través de una secuencia de mamíferos. Ameghiniana 25:99-110.

TonNI, E. P., A. L. CIONE, AND A. J. FIGINI. 1999. Predominance of arid climates indicated by mammalsin the pampas ofArgentina during the Late Pleistocene and Holocene. Paleogeography, Palaeoclimatology, Palaeoecology 147:257-281.

Ubilla, M., And A. RinderkneCht. 2001. Consideraciones sobre el género Galea Meyen, 1831 (Rodentia, Caviidae), su registro en el Pleistoceno de Uruguay y descripción de una nueva especie extinguida. Boletín de la Real Sociedad Española de Historia Natural 96:111-122.

Ubilla, M., And A. RinderkneCht. 2014. Comparative analysis of Galea (Rodentia, Caviidae) and expanded diagnosis of Galea ortodonta Ubilla and Rinderknecht, 2001 (Late Pleistocene, Uruguay). Geobios 47: 255-269.

Vizcaíno, S. F., y M. S. BARgo. 1993. Los armadillos de la toma (partido de Coronel Pringles) y otros sitios arqueológicos de la provincia de Buenos Aires. Consideraciones paleoambientales. Ameghiniana 30:435-443.

Vizcaíno, S. F., M. S. Bargo, G. H. Cassini, and N. Toledo. 2016. Forma y función en paleobiología de vertebrados. Editorial de la Universidad Nacional de La Plata (EDULP).

Vucetich, M. G., M. Arnal, C. M. Deschamps, M. E. Perez, and E. C VIEYTES. 2015. Evolution of Caviomorph rodents: A complete phylogeny and timetree for living genera. Pp. 11-62 in Biology of Caviomorph rodents: Diversity and evolution (Vasallo, A.I. y D. Antenucci, eds.). Sociedad Argentina para el Estudio de los Mamíferos Series A, Mammalogical Research/ Investigaciones Mastozoológicas, Buenos Aires, Argentina.

Associated editor: Jorge Servin

Submitted: April 21, 2017; Reviewed: July 27, 2017;

Accepted:July27, 2017; Published on line:September 23, 2017. 


\section{Appendix 1.}

List of the Galea specimens studied in the present work, and their record localities in Argentina, Bolivia and Paraguay. These materials are deposited in the following collections: CFA, Collection of Mammals of Fundación de Historia Natural Félix de Azara (Buenos Aires, Argentina); CMI, Collection of Mammals of Instituto Argentino de Investigación de Zonas Áridas (Instituto Argentino de Investigaciones de Zonas Áridas, Mendoza, Argentina); CML, Collection of Mammals of Facultad de Ciencias Naturales e Instituto Miguel Lillo (Facultad de Ciencias Naturales e Instituto Miguel Lillo, San Miguel de Tucumán, Argentina); CNP, Collection of Mammals of Centro Nacional Patagónico (Centro Nacional Patagónico, Puerto Madryn, Argentina) MACN$\mathrm{Ma}$, Museo Argentino de Ciencias Naturales "Bernardino Rivadavia" (Buenos Aires, Argentina) MNHNP, Collection of Mammals of Museo Nacional de Historia Natural de Paraguay (Asución, Paraguay); UACh, Collection of Mammals of Universidad Austral de Chile (Valdivia, Chile):

Galea leucoblephara demissa ( $n=77)$ : Argentina: Catamarca: Hualfín, Casa de Piedra (CML 917). Chaco: General Güemes, Misión Nueva Pompeya (MACN-Ma 22589). Formosa: Matacos, Ingeniero Guillermo N. Juárez (MACN-Ma 47.391). Jujuy: San Pedro, Ingenio La Esperanza (CFA 4704). La Rioja: Chilecito, Chilecito (MACN-Ma 34.189, 34.272); Coronel Felipe Varela: Villa Unión (MACN-Ma 34.190, 34.193); Famatina, Las Pirquitas (MACN-Ma 34.194, 34.200); Famatina, Tres Cerros (MACN-Ma 34.196, 34.198). Salta: Anta, Los Colorados, 17 km E Santo Domingo (CML 3052); El Quebrachal (MACN-Ma 36.312, 36.313, 36.314, 36.315, $36.685,36.752,36.755,36.761,36.764,36.766,36.767$, $36.771,36.772,36.774,36.775,36.776,36.778,36.779$, $36.783,36.784,36.785,36.786,36.790,36.791)$; General José de San Martín, Dragones (MACN-Ma 36.262); Metán, Metán (MACN-Ma 17362); Metán, La Represa, 500 mts. (MACN-Ma 30.363, 30.368); Orán, Orán (MACN-Ma 16227); Río Pescado (CFA 4307); Tabacal (MACN-Ma 16227); Finca San Javier, 8,5 km SE Joaquín V. González (CMI 3021); San Javier-Pozo Largo, 19 km SE Joaquín V. González (CMI 3023); Puesto Yuchán, camino a Salta forestal, $35 \mathrm{~km} \mathrm{~N}$ Joaquín V. Gonzalez (CMI 3022). Santiago del Estero: Banda, Sotelillo (CML 509); Choya, Villa La Punta (CFA 10809); Pellegrini, Santa Isabel (MACN-Ma 17351, 17352); sin localidad precisa (MACN-Ma 35.137, 35.138). Tucumán: km 81 de la R307, Tafí del Valle, 12 km O de Quebradita (CMI 4160); Trancas: Cerro Vipos, 1000 m s.n.m. (MACN-Ma 30.167, 30.169-30.171); Cumbres Calchaquies, cercanas a Vipos (MACN-Ma 30.167); Leales (CFA 111); Villa M. Paz (CFA 4370). Paraguay: Alto Paraguay: Estancia "Tres Marias"(TK 62443); Palmar de Las Islas (TK 65319, 65391). Boquerón: (TK130781, 130786, 130807, 13785); Parque Cué (TK 63298, 63371); Parque Nacional "Teniente Enciso" (TK 65029); Parque Nacional "Teniente Enciso", $3 \mathrm{Km}$. al Sur del fortín Teniente Enciso (MNHNP 753); Parque Nacional "Teniente Enciso", cerca del Puesto Siracua (TK66471); Rodeo Trebol, 5 Km. al NE de Loma Plata (TK 130764). Parque Nacional "Defensores del Chaco", 500 mts. al Oeste de Madrejón (MNHNP 755); Presidente Hayes, Estancia "Samaklay" (TK 122211, 122212, 122226).

Galea leucoblephara leucoblephara $(n=11)$ : Argentina: Córdoba: Pocho, Tala Cañada (MACN-Ma 14745); San Alberto, Pampa de Achala (MACN-Ma 14706); San Javier, La Paz (MACN-Ma 29.10); Santa María, Alta Gracia, Falda del Carmen (MACN-Ma 14705). Mendoza: Mendoza (IZH 17); Santa Rosa, Reserva de Biosfera de Ñacuñan (UACH 6168); Tunuyán, Manzano Histórico (CMI 4160). San Juan: 9 de Julio, Monte de Oro (CMI 7065), San Juan (MACN-Ma 29.876); San Luis: General Pedernera, Villa Mercedes (MACN-Ma 50.49); Merlo, El Rincón (MACN-Ma 29.51).

Galea leucoblephara littoralis $(n=22)$ : Argentina: Buenos Aires: Bahía Blanca (MACN-Ma 25281); Balcarce, Napaleofú (MACN-Ma 16405); Benito Juárez, Benito Juárez (MACN-Ma 54.134, 54.135); General Pueyrredón, Sierra de los Padres (MACN-Ma 13064); Necochea, Quequén (MACN-Ma 28.11); Torquinst, Abra de la Ventana (MACN-Ma 14936); Villarino, Algarrobo (MACN-Ma 22607). Chubut: Biedma, Arroyo Valdes (US s/n); Puerto Madryn, Playa Kaiser (CNP s/n, CNP s/n, CNP s/n); Escalante, Valle Hermoso (MACN-Ma 29.927); La Pampa: Caleu Caleu (MACN-Ma 13335, 13336, 15500); Hucal, Laguna Colorada Grande (MACN-Ma 15500); Lihuel Calel, Parque Nacional Lihué-Calel (MACN-Ma 20845); Pichi Mahuida, Estación de Aforos №44 (CNP 3619). Neuquén: Collón Curá (CFA 5567). Rio Negro: Avellaneda: Choele Choel (MACN-Ma 28.141). Santa Cruz: Deseado, 20 km al Norte de Caleta Olivia (MACN-Ma 22838). 
TAXONOMY OF GALEA TIXIENSIS

216 THERYA Vol. 8 (3): 209-216 